\title{
RESEARCH PRODUCTIVITY OF ACCOUNTING PROFESSORS AROUND A CHANGE IN INSTITUTIONAL AFFILIATION
}

Thomas D. Dowdell, Jr.*

North Dakota State University

David N. Herda

Louisiana Tech University

Mina J. Pizzini

Texas State University

Laura Trude

North Dakota State University

*Address for correspondence: Thomas D. Dowdell, Jr., North Dakota State University, College of Business, NDSU Dept. 2410, PO Box 6050, Fargo, ND 58108-6050, USA.

thomas.dowdell@ndsu.edu

Running head: Research Productivity of Accounting Professors 


\title{
RESEARCH PRODUCTIVITY OF ACCOUNTING PROFESSORS AROUND A CHANGE IN INSTITUTIONAL AFFILIATION
}

\author{
Thomas D. Dowdell, Jr., David N. Herda, Mina J. Pizzini, Laura Trude
}

\begin{abstract}
This study examines the scholarly output of accounting researchers in time periods surrounding a change in university affiliation. Our expectation that publishing activity will increase in periods around an institutional change is based on expectancy theories and informed by studies on the contract year performances of professional athletes. Using a sample of 635 accounting professors who switched universities between 2008 and 2014, we find evidence that accounting authors who switch universities publish more in the years around a switch compared to other years. Our research contributes to the literature on changes in university affiliation by documenting a contract year phenomenon operating within accounting academia. Practical implications for college administrators are discussed.
\end{abstract}

Keywords: Research productivity; publishing; academic employment; faculty turnover 


\section{INTRODUCTION}

Universities increasingly emphasize the importance of publishing in accounting academia (Bergner, Filzen, \& Wong, 2016; Fogarty \& Jonas, 2013; Swanson, 2004), and publication success is essential to career advancement for many accounting professors (Campbell, Gaertner, \& Vecchio, 1983). Alternative academic appointments at higher compensation levels are often available to accounting faculty with publication success (Fogarty, 2009). Higher paying appointments are particularly salient among resident faculty where a shortage of new accounting doctorates creates salary compression or inversion (Boyle, Carpenter, \& Hermanson, 2015; Fogarty, 2009). Many universities do not significantly increase resident faculty salaries for higher research productivity; thus, resident faculty must move to another university to obtain a sizable pay increase. For some, the lure of an alternative academic appointment with a higher salary or other desired features may motivate them to ramp up research productivity in an effort to position themselves as attractive candidates in the job market. At the same time, other faculty who are currently successful in publishing may seize the opportunity provided by their recent success to look for opportunities at preferred institutions.

The purpose of this study is to examine the scholarly output of accounting researchers in time periods surrounding a change in institutional affiliation. Motivated by expectancy theories and informed by studies on the contract year performances of professional athletes (Martin, Eggleston, Seymour, \& Lecrom, 2011; White \& Sheldon, 2014), we compare, for the same individual, research productivity around the time of a change in institution to research productivity during non-transitional years. Our research contributes to the change in institutional affiliation literature by documenting a contract year phenomenon operating within accounting academia. Previous research (Beckmann \& Schneider, 2013; Chan, Chang, Tong, \& Zhang, 2014; Chan, 
Chen, \& Steiner, 2002) finds that professors who switch institutions (hereafter labeled "switchers") publish more than non-switchers. This is the first study to find that switchers publish more during the time period around a switch than they do in other years.

For our full sample, we find a significant increase in research productivity around accounting professors' changes in institutional affiliation. This result is partially driven by a large number of switches that occur four to nine years after faculty receive their doctorate- $\mathrm{a}$ high publishing period related to faculty development in their early career and the tenure process. However, we still find some evidence of a transitional effect for subsamples of switches that occur at least seven or 15 years after graduation, and for switches among associate and full professors. We also find the transitional effect is similar between switches to more and less research-focused institutions.

Our study has important implications for college administrators. Deans and department chairs seek accounting professors who will enhance their programs through consistent publication success. Our findings may alert administrators to the possibility of the contract year syndrome operating among some job candidates as they evaluate publication records. Administrators should be prepared to lose productive researchers to other institutions and expect research productivity to fall off for newly hired faculty if their college/department is not successful in maintaining an environment that promotes scholarly motivation among resident faculty.

Although this study examines research productivity, productivity in teaching and service is also potentially correlated with changes in institutional affiliation. We focus entirely on research because universities increasingly emphasize the importance of publishing in accounting academia (Bergner et al., 2016; Fogarty \& Jonas, 2013; Swanson, 2004), and we can objectively measure 
research productivity. Our investigation into research productivity has the potential to motivate future researchers to consider studying the effects of institutional changes on less-quantifiable indicators of academic productivity, such as teaching effectiveness and student learning.

This paper is organized as follows. The following section provides background and develops our hypotheses. Next, we describe the testing methodology and variable measurement, followed by a presentation of the empirical results. Finally, we conclude with a review of our findings and a discussion of the study's contributions, limitations, and implications.

\section{BACKGROUND AND HYPOTHESES DEVELOPMENT}

Prior empirical studies in disciplines outside of accounting find that research productivity is associated with faculty changing institutions. To illustrate, Chan et al. (2002) examine publishing activity among 4,990 authors from 923 academic institutions in 16 finance journals from 1990 through 2001. They rank institutions based on journal page counts and focus on 88 authors who made an "upward" switch. Chan et al. (2002) find that research records for these individuals are approximately two times stronger than those of average faculty members at the destination institution who did not switch.

Beckman and Schneider (2013) examine the effect of publication output on the probability of receiving an appointment offer using publication and offer data for 889 German academic economists from 1981 through 2006. They calculate publication output using the number of publications weighted by journal quality and the number of authors. They find that the probability of an appointment offer is positively related to the five- and three-year averages of publication 
output. They also find that post-appointment publication output decreases for those receiving an appointment, particularly for faculty with high annual publication output.

Schwab (1991) studies 259 tenure-track social science faculty members that were employed at a research university in 1980-1981 and had not retired or died by 1986-1987. Using the log of the number of citations as his research performance measure, he finds that among tenured faculty, those with higher research performance were more likely to switch schools; conversely, among untenured faculty, those with lower research performance were more likely to switch schools.

These three studies find that research productivity is higher for faculty changing institutions compared to faculty staying with the same institution, although Schwab (1991) only finds this for tenured faculty. One explanation for these results is that faculty who change institutions have higher research productivity compared to other faculty who remain with the same institution. Our study examines the related but previously unexplored issue of whether individual faculty members increase their research productivity in an effort to enhance their market value when they want to switch institutions. In contrast to the above prior research that compares publication output between switchers and non-switchers, our paper examines publication output among switchers over time.

Survey research suggests that faculty believe higher research productivity leads to better future job opportunities. Chen and Zhao (2013) surveyed 320 faculty members, including 69 accounting professors, at ten non-doctoral business colleges. One of their lines of questioning pertained to the perceived impact of research productivity on achieving various extrinsic rewards, including finding a better job at another university. Most participants surveyed felt that research productivity impacts alternative job opportunities. Smart (1990) surveyed doctoral-qualified 
faculty at 190 universities in various disciplines and find a significant association between tenured professors' recent research productivity (i.e., recent publications and whether they were currently working on projects expected to lead to publication) and intention to leave their current school for an alternative appointment.

The notion of individuals increasing their effort and productivity during periods in which an extrinsic motivator is salient is certainly not unique to academia. Expectancy theories of motivation posit that individuals will exert greater effort if they anticipate that their performance will lead to higher compensation or other extrinsic rewards (Bandura, 1997; Behling \& Starke, 1973; Jex \& Britt, 2008; Vroom, 1964). In the world of sport, the contract year phenomenon is a theory asserting that players will perform better in the final year of their contract than they have in previous years in order to receive attractive offers on the free-agent market (Berri \& Krautmann, 2006; Martin et al., 2011; White \& Sheldon, 2014). Indeed, several studies find that professional athletes perform better during contract years, consistent with expectancy theory (Holden \& Sommers, 2005; Martin et al., 2011; Stiroh, 2007; White \& Sheldon, 2014). Based on the above, we hypothesize that:

H1. Accounting professors who switch universities will publish more in the time period around the switch than they do in other years.

While most institutions generally consider research productivity, instructional ability, and aptitude for service in evaluating faculty, schools do not place equal weight on these three factors. More research-focused institutions place greater weight on research productivity than less research-focused institutions. To obtain employment at a top research institution, faculty must demonstrate that they can consistently publish in high-impact journals. Shortcomings in the 
classroom may be overcome by a very strong research record. Consequently, we expect that faculty who switch to more research-focused schools will publish more around the time of their transitions than those who switch to less research-focused institutions, as stated in our second hypothesis:

H2. Accounting professors who switch to more research-focused universities will publish more in the time period around the switch relative to other years as compared to accounting professors who switch to less research-focused universities.

\section{METHOD}

\section{Sample}

Data were gathered from the Brigham Young University (BYU) accounting research ranking database (http://www.byuaccounting.net/rankings) and Hasselback's Accounting Faculty Directory (hereafter, Hasselback). Our sample consists of all accounting professors who switched institutions between 2008 and 2014 and published in the set of accounting journals tracked by BYU. Researchers at BYU began recording accounting professors' institutional affiliations in 2008, so the first possible switch year using their database is 2009. At our request, they provided data on author changes including switches in university affiliation, retirements, deaths, and transitions to practice. We used Hasselback to identify switches for 2008. These data yielded 1,190 unique authors with a change during 2008-2014. We excluded from the sample 191 retirees, 41 practitioners, 29 decedents, 32 recent doctoral program graduates whose only switch during the sample period represented a transition from their doctoral school to an employing university (first appointment), three authors with unknown switch years, and 259 authors with unknown institutional affiliation or Ph.D. graduation year. This results in a sample of 635 switchers. ${ }^{1}$ Each 
author-year combination constitutes an observation with a maximum of seven observations (20082014) per switcher, resulting in a sample of 4,312 observations.

The BYU database was limited to articles and professors published in 13 accounting journals - the 11 journals that make up the Coyne, Summers, and Wood (2010) journal index and two accounting education journals. The 13 journals in alphabetical order are: Accounting, Organizations and Society; The Accounting Review; Auditing: A Journal of Practice \& Theory; Behavioral Research in Accounting; Contemporary Accounting Research; Issues in Accounting Education; Journal of Accounting and Economics; Journal of Accounting Education; Journal of Accounting Research; Journal of Information Systems; Journal of Management Accounting Research; Journal of the American Tax Association; and Review of Accounting Studies. Although any such journal list is subjective, several prior studies on accounting research productivity use the Coyne et al. journal index (e.g., Bailey, 2015; Coyne et al., 2010; Glover, Prawitt, Summers, \& Wood, 2012; Pickerd, Stephens, Summers, \& Wood, 2011; Stephens, Summers, Williams, \& Wood, 2011).

Ideally, all reputable journals (both within and outside of accounting) would be considered in our analysis, but this is not practicable. Excluding journals outside of the 13 contained in the BYU database limits the generalizability of our results if authors who publish in the excluded journals (and the institutions that hire them) differ fundamentally from those who publish in the BYU-listed journals. One possible difference is that authors who publish in the BYU-listed journals may place more emphasis on research compared to authors who publish in the excluded journals. Consequently, any increase we find in research productivity for BYU-listed authors during transitional periods may not generalize to other accounting authors because the latter might place less emphasis on research. However, we do not believe this to be the case. Fogarty (2009) 
finds that although non-doctoral-granting institutions may place greater weight on instructional ability and service than their doctoral-granting peers, publication records still dominate hiring decisions because outside institutions can assess publication proficiency much more accurately than they can evaluate expertise in service and teaching. Accordingly, regardless of whether a professor seeks to move between institutions in the highest decile of the top 200 accounting departments or the lowest decile, publication success is still the most important determinant of an academic's ability to move (Bergner et al., 2016).

To assess the limitations of using the BYU journal list, we compared it to the broader Australian Business Deans Council (ABDC) Journal Quality List. The BYU list includes seven out of the $11 \mathrm{~A}^{*}$ journals from the ABDC list within the subjects of accounting or tax. The BYU list excludes Management Accounting Research, The European Accounting Review and the two A* tax journals: British Tax Review and Canadian Tax Journal. Five of the remaining six BYU journals are A-rated ABDC journals within the subjects of accounting or tax. The BYU list excludes 17 A-rated accounting and eight A-rated tax journals on the ABDC list. Finally, the BYU list includes Journal of Accounting Education, which is rated B in the ABDC list.

Our use of the BYU journal list has important implications for the interpretation of our results. Schools placing less emphasis on research "count" many reputable journals that are not included in the BYU list when evaluating faculty. Conversely, top research institutions typically only consider the accounting journals tracked by BYU, along with highly-ranked journals in related disciplines. Consequently, the number of publications may not differ between more and less research-focused schools. Rather, the quality of publications may simply be higher in more research-focused schools than in less research-focused schools. That is, while faculty at less research-focused schools publish the same number of articles as faculty at more research-focused 
schools, they publish in journals that are not tracked by BYU. If faculty at both more and less research-focused schools increase their publishing during transitional years, we will only observe it for the more research-focused school faculty. This will bias our analysis against finding support for our first hypothesis. On the other hand, this will bias our analysis in favor of finding support for our second hypothesis.

\section{Measures}

Publication count is a widely used metric for determining research productivity. See, for example, Andrews and McKenzie (1978); Bublitz and Kee (1984); Jacobs, Hartgraves, and Beard (1986); Hasselback and Reinstein (1995); Stevens and Stevens (1996); and Stephens et al. (2011). Citation analysis is an alternative measure for research productivity usually intended to differentiate higher quality articles but, as Hasselback, Reinstein, and Schwan (2000) point out, citations can be influenced by the reputation of the author, the sensitivity of the subject matter, and the journal's circulation/coverage. Publication count is more objective because it avoids the biases of perceptions, such as primacy, years since publication, and superstar (Stephens et al., 2011). While citation analysis attempts to take the impact of an article into consideration, it can also give undue credit to negatively perceived works and relies on the author's reputation, journal circulation, and topic interest (MacRoberts \& MacRoberts, 1989). Additionally, factors determining which articles are cited do not always indicate quality or reflect influence (MacRoberts \& MacRoberts, 1996; Reinstein, Hasselback, Riley, \& Sinason, 2011).

For each individual $(i=1 \ldots 635)$ in our sample, we obtained the number of publications (PUBNUM $\left.M_{\mathrm{it}}\right)$ for each year $(t=1 \ldots 7)$. Consistent with Fogarty and Jonas (2013) and Bailey (2015), publications are not adjusted for coauthors, essentially giving full credit to each author. A 
publication dummy variable $\left(P U B_{\mathrm{it}}\right)$ is also used in the analyses. $P U B_{\text {it }}$ is equal to 1 if professor $i$ had one or more publications during year $t$, and 0 otherwise.

To differentiate transitional period publications from non-transitional period publications, each author-year observation is coded as either a transitional or non-transitional year. Transitional years include the year prior to a switch in university affiliation, the year of the switch, and the year after the switch. The variable $T R A N S Y R_{\text {it }}$ is coded to 1 for transitional years, and 0 otherwise. A three-year transitional period is selected to assess switchers' research productivity leading up to a change in school affiliation. Articles published in the year of a switch, and in many cases the year after a switch, likely pertain to projects begun prior to the switch due to the time lag inherent in the publication process and, therefore, are also considered appropriate indicators of research productivity leading up to a change in institutional affiliation. Wood (2016) finds the mean (median) publication time from original submission to acceptance for accounting articles published in Accounting, Organizations and Society; Contemporary Accounting Research; Journal of Accounting \& Economics; Journal of Accounting Research; Review of Accounting Studies; and The Accounting Review to be 1.8 (1.7) years. Authors in our sample who switched in 2014 only have a two-year transitional period. We used Hasselback to identify switches in 2015 for authors in our sample so that 2014 could be correctly coded as a transitional year. To maximize our sample size, we do not require that switches in our sample have all three transitional years.

Recognizing that tenured and untenured faculty face different incentives for publishing, we also include a proxy for tenure in our analyses. The dummy variable $T E N U R E_{\mathrm{it}}$ is assigned a value of 1 for authors who graduated from their doctoral program at least seven years prior to the year being observed, and 0 otherwise. In some of our testing we separately examine switches which occur at least seven years after authors graduate from their doctoral programs. We use this length 
of time because six years is the typical pre-tenure period in U.S. institutions. However, faculty may not achieve tenure within six years of earning their doctorate because they may switch schools early in their career. Consequently, we also use an alternative tenure proxy based on authors' academic rank from Hasselback. We match our seven years of BYU data with six annual Hasselback directories (there is no 2010-2011 directory). We consider faculty with an academic rank of professor or associate professor (assistant professor) as tenured (untenured). Glover, Prawitt, \& Wood (2006) find that accounting faculty took an average of 6.29 (median $=6.0$ ) years to achieve the associate professor rank. They also find that $77 \%$ of promoted faculty responding indicated that the date of their promotion to associate professor matched their tenure date. Our alternative tenure proxy $H T E N U R E_{\text {it }}$ is equal to 1 (0) if an author has a rank of professor or associate professor (assistant professor) in all years available in the Hasselback directories with either five or six years available.

We also control for the author's doctoral program and their current and previous institution because prior accounting studies have demonstrated a strong relationship between publication success and both the doctoral origin of an author and their current employing institution (Fogarty \& Jonas, 2013; Fogarty \& Yu, 2010). Institutional prestige has been found to have a greater impact on publication success within the accounting discipline relative to any other business discipline (Swanson, Wolfe, \& Zardkoohi, 2007). ${ }^{2}$ Doctoral training at top accounting programs may lead to greater success in publishing (Burke, Fender, \& Taylor, 2008; Fogarty \& Jonas, 2013). Accounting professors trained at top doctoral programs tend to take faculty positions at other top universities (Fogarty \& Ruhl, 1997; Maranto \& Streuly, 1994). To control for institutional affiliation, we obtained a switcher's doctoral school, former school (i.e., the institution from which the author switched), and target school (i.e., the institution to which the author switched). This data was 
obtained from the BYU database. The top 40 accounting programs according to Coyne et al. (2010) and the top 40 accounting doctoral programs according to Stephens et al. (2011) were identified. Top 40 programs were coded to 1 and 0 otherwise. ${ }^{3}$ In some analyses we control for whether a switcher's former and target schools have accounting doctoral programs, which we obtain from Hasselback.

Finally, in some analyses we control for whether a faculty member has an administrative position because administrative responsibilities can impact research productivity (Pickerd et al., 2011). We obtained from Hasselback any administrative position a faculty member had at their institution.

\section{RESULTS}

\section{Main Results}

Table 1 reports descriptive statistics and correlations. The correlations between the transitional year dummy variable $T R A N S Y R_{\text {it }}$ and both the publication dummy $P U B_{\text {it }}$ and continuous variable $P U B N U M_{\text {it }}$ are significantly positive, which is consistent with $\mathrm{H} 1$. Approximately $70 \%$ of our sample observations pertain to authors who graduated from their doctoral programs at least seven years prior to the year being observed (i.e., $T E N U R E_{\mathrm{it}}=1$ ). $T E N U R E_{\mathrm{it}}$ is negatively correlated with $P U B_{\text {it }}$ and $P U B N U M_{\text {it, }}$, reflecting a post-tenure drop-off in publishing.

[Insert Table 1 about here]

Fig. 1 presents three graphs of important relations in our sample. Panel A reports mean $P U B_{\text {it }}$ and $P U B N U M_{\text {it }}$ by event year (number of years before or after the switch). Consistent with H1, mean $P U B_{\text {it }}$ and $P U B N U M_{\text {it }}$ tend to be higher in the years around the switch. Both $P U B_{\text {it }}$ and $P U B N U M_{\text {it }}$ are highest in the year before the switch (year -1). 
Fig. 1 Panel B shows mean $P U B_{\mathrm{it}}$ and $P U B N U M_{\mathrm{it}}$ by years after Ph.D. graduation. Mean $P U B_{\mathrm{it}}$ and $P U B N U M_{\mathrm{it}}$ tend to be highest in years four through nine after graduation. During these years, authors may be publishing articles that they started early in their careers. The increased publishing we observe in Panel A in the event years around switches could be caused by a lot of switches occurring in years four through nine.

Fig. 1 Panel C reports the number of switches by years after Ph.D. graduation. The highest number of switches in a year (56) occurs seven years after graduation and $289(41 \%)$ of the 704 switches in our sample occur in years four through nine. Consequently, the high mean $P U B_{\text {it }}$ and $P U B N U M_{\mathrm{it}}$ we observe around the switch years could be caused by the higher publishing faculty members accomplish four to nine years following their Ph.D. In light of the results in Panels B and $\mathrm{C}$, we perform our analysis both on the full sample and on subsamples based on an author's career stage.

[Insert Fig. 1 about here]

Table 2 reports research productivity in transitional and non-transitional years. As presented in Panel A, mean $P U B_{\text {it }}$ and $P U B N U M_{\text {it }}$ are significantly higher for transitional years (26.9\% and 0.33) compared to non-transitional years (22.6\% and 0.26). Panel A also reports the results for tests of differences between individual authors' mean $P U B_{\text {it }}$ and $P U B N U M_{\text {it }}$ for transitional and non-transitional years. This test controls for individual author effects. The results indicate that authors' research productivity is significantly higher during their transitional years compared to their non-transitional years. Consequently, $\mathrm{H} 1$ is supported.

[Insert Table 2 about here]

Table 2 Panel B presents results for the subsample of switches that occur at least seven years after the author's Ph.D. graduation. Multiple switchers are included in this sample if all of 
their switches occurred at least seven years after their Ph.D. This is our first proxy for switches that occur after an author receives tenure. Similar to Panel A, we find that mean $P U B_{\text {it }}$ and $P U B N U M_{\text {it }}$ are significantly higher for transitional years $(24.5 \%$ and 0.30$)$ compared to nontransitional years $(21.5 \%$ and 0.25$)$. The differences between 446 individual authors' mean $P U B_{\text {it }}$ and PUBNUM $M_{\mathrm{it}}$ for transitional and non-transitional years are significantly positive for all four tests (one-tailed $p$-values ranging from 0.014 to 0.086 ).

Table 2 Panel C presents results for the subsample of switches that occur at least 15 years after the author's Ph.D. graduation. These are likely post-tenure switches because of the length of time after the author's Ph.D. Similar to Panels A and B, we find that mean $P U B_{\text {it }}$ and $P U B N U M_{\text {it }}$ are significantly higher for transitional years $(19.0 \%$ and 0.24$)$ compared to non-transitional years (15.6\% and 0.19). The differences between 200 individual authors' mean $P U B_{\text {it }}$ and $P U B N U M_{\text {it }}$ for transitional and non-transitional years are significantly positive for three of the four tests (onetailed $p$-values ranging from 0.046 to 0.142 ).

Table 2 Panel D presents results for switches of authors identified in Hasselback as "Associate" or "Professor" in all years available with a minimum of five during our sample period. These switches likely occur after tenure because we require these authors to be ranked as associate or full professors throughout the sample period. Similar to the previous panels, we find that mean $P U B_{\text {it }}$ and $P U B N U M_{\text {it }}$ are significantly higher for transitional years $(31.7 \%$ and 0.41$)$ compared to non-transitional years (27.4\% and 0.34). However, the differences between 174 individual authors' mean $P U B_{\text {it }}$ and $P U B N U M_{\text {it }}$ for transitional and non-transitional years are significantly positive for only one of the four comparisons (one-tailed $p$-values ranging from 0.060 to 0.286 ).

In untabulated analysis we calculate results for the subsample of switches that occur less than seven years after the author's Ph.D. graduation and for authors identified in Hasselback as 
“Assistant." For switches less than seven years after the author's Ph.D., we again find that mean $P U B_{\mathrm{it}}$ and $P U B N U M_{\mathrm{it}}$ are significantly higher for transitional years (33.3\% and 0.39$)$ compared to non-transitional years (25.8\% and 0.29). Also, the differences between 164 individual authors' mean $P U B_{\text {it }}$ and $P U B N U M_{\text {it }}$ for transitional and non-transitional years are $4.4 \%$ and 0.06 , respectively, and are significantly positive (one-tailed $p$-values ranging from 0.048 to 0.082 ).

For switches of assistant professors according to Hasselback, we again find that mean $P U B_{\mathrm{it}}$ and $P U B N U M_{\mathrm{it}}$ are significantly higher for transitional years (30.5\% and 0.34$)$ compared to non-transitional years (24.0\% and 0.27). Also, the differences between 104 individual authors' mean $P U B_{\text {it }}$ and $P U B N U M_{\text {it }}$ for transitional and non-transitional years are $7.4 \%$ and 0.08 , respectively, and are significantly positive (one-tailed $p$-values ranging from 0.018 to 0.048 ). These differences are higher and more statistically significant as compared to the differences for associate/full professors in Panel C.

We use two multivariate models to test the association between transitional years and accounting authors' research productivity. Model 1, a binary logit model, is our primary research model:

$$
\begin{aligned}
\operatorname{Prob}(P U B=1)= & \beta_{0}+\beta_{1} \text { TRANSYR }+\beta_{2} \text { TENURE }+\beta_{3} \text { TRANSYR } * \text { TENURE }+ \\
& \beta_{4} \text { TOPPHDSCHOOL }+\beta_{5} \text { TOPSCHOOL }+\beta_{6} \text { FMRTOPSCHOOL }+\varepsilon
\end{aligned}
$$

The variables are defined in Table 1. Model 2 is a supplemental OLS regression model:

$$
\begin{aligned}
\text { PUBNUM }= & \beta_{0}+\beta_{1} \text { TRANSYR }+\beta_{2} \text { TENURE }+\beta_{3} \text { TRANSYR *TENURE }+ \\
& \beta_{4} \text { TOPPHDSCHOOL }+\beta_{5} \text { TOPSCHOOL }+\beta_{6} \text { FMRTOPSCHOOL }+\varepsilon \quad \text { (2) }
\end{aligned}
$$

The dependent variable in the OLS model is PUBNUM, representing the number of publications for an author in a given year. Of the total 4,312 author-year observations in our sample, PUBNUM 
$=0$ for 3,255 observations, $P U B N U M=1$ for 892 observations, $P U B N U M=2$ for 134 observations, $P U B N U M=3$ for 27 observations, $P U B N U M=4$ for three observations, and $P U B N U M=5$ for one observation. In both regressions, the observations for the same author are not independent, so we cluster standard errors by author when we calculate coefficient $p$-values. We also do this in the remaining regressions.

Table 3 Panel A reports the results for the multivariate regressions conducted on Models 1 and 2. H1 predicts that accounting authors will publish more around a change in university affiliation. Since we include TRANSYR and TRANSYR*TENURE in the regression the coefficient for TRANSYR $\left(\beta_{1}\right)$ estimates the transition effect for untenured faculty, whereas $\beta_{1}+\beta_{3}$ (coefficient for the interaction term) is the effect for tenured faculty. We find that the transition effects for untenured $\left(\beta_{1}\right)$ and tenured $\left(\beta_{1}+\beta_{3}\right)$ faculty are significantly positive in the logit and OLS models (two-tailed $p$-values ranging from 0.003 to 0.014 ). These results provide evidence in support of H1.

\section{[Insert Table 3 about here]}

As expected, authors trained in top doctoral programs and authors currently and/or formerly affiliated with top accounting programs are more likely to publish. The OLS results are quantitatively and qualitatively similar to the logit results.

Table 3 Panel B presents regression results for authors identified in Hasselback as "Assistant," "Associate," or "Professor" in all years available with a minimum of five during our sample period. We assume switches for authors identified as "Assistant" occur before tenure $(H T E N U R E=0)$, and switches for authors identified as "Associate" or "Professor" occur after tenure $(H T E N U R E=1)$. We find that the transition effects for pre-tenure $\left(\beta_{1}\right)$ and post-tenure $\left(\beta_{1}\right.$ $+\beta_{3}$ ) switches are significantly positive in the logit model (two-tailed $p$-values $=0.054$ and 0.084 , 
respectively). In the OLS model, we find the transition effect is significant for post-tenure switches $(p$-value $=0.081)$ but not for pre-tenure switches $(p$-value $=0.107)$. These results provide partial evidence in support of $\mathrm{H} 1$.

As reported in Table 3 Panel B, authors trained in top doctoral programs and authors currently and/or formerly affiliated with top accounting programs are more likely to publish, which is consistent with the Panel A results. In contrast to Panel A, we find that associate and full professors $(H T E N U R E=1)$ publish more than assistant professors $(H T E N U R E=0)$ in our Hasselback sample. Finally, we find that faculty holding administrative positions publish less than those who do not hold them.

Table 3 Panel C presents regression results for switches that occur at least 15 years after an author graduates with their Ph.D. (the subsample for Table 2 Panel C). We assume all of these switches are post-tenure and therefore do not include a tenure dummy or interaction term in the regressions. For this subsample, we find that the transition effects are significantly positive in the logit model (two-tailed $p$-value $=0.062)$ but not in the OLS model ( $p$-value $=0.129$ ). Consequently, we find some evidence supporting $\mathrm{H} 1$ even in switches occurring a long time after an author's Ph.D. graduation, consistent with the results in Table 2 Panel C.

Table 4 reports results for tests to examine whether there is a larger transition effect on research productivity for authors switching to more research-focused universities as compared to authors switching to less research-focused schools (H2). We use two proxies for research focus: first, our TOPSCHOOL dummy variable (based on the top 40 research schools from Coyne et al. [2010]) and second, whether the university has an accounting doctoral program. In these tests we limit our sample to authors who switched once during the sample period. 
Table 4 Panel A reports that 91 authors $(53+38)$ switched to a top 40 program. Table 4 Panel B reports results from logit and OLS regressions testing H2. Our test variable is the interaction term TRANSYR*TOPSCHOOL. Its coefficient is not significant in either regression (two-tailed $p$-values $=0.875$ and 0.714 , respectively) which does not support $\mathrm{H} 2$. Other results in the two regressions are similar to our main results in Table 3 Panel A, except that the transition effect for faculty switching to top schools $\left(\beta_{1}+\beta_{3}\right)$ is not significant in the logit regression ( $p$-value $=0.227$.

Table 4 Panel C reports that 164 authors $(129+35)$ switched to a university with an accounting doctoral program. We consider a university to have an accounting doctoral program if it is listed in the Hasselback 2015-2016 edition, the program is active, and the program has at least 10 graduates in its history. Since Hasselback only provides this information for U.S. doctoral programs we only included U.S. universities in this test.

Table 4 Panel D reports results from logit and OLS regressions testing $\mathrm{H} 2$ but here our test variable is the interaction term $T R A N S Y R * P H D$ where $P H D$ is a dummy variable equal to 1 if the university has an accounting doctoral program and 0 otherwise. Similar to the results reported in Panel B, the interaction term is not significant in either regression $(p$-values $=0.947$ and 0.441$)$, providing no support for $\mathrm{H} 2$. In the Panel D regressions, the coefficients for TRANSYR and $T R A N S Y R^{*} P H D$ added together are significant in the OLS regression but not in the logit regression. The coefficient for TRANSYR is not significant in either regression. The remaining results for the two regressions are similar to our main results reported in Table 3 Panel A.

Sensitivity Analyses 
Our sample includes 59 authors who switched twice during the sample period and seven authors who switched three times for a total of 139 switches with 309 transitional and 161 nontransitional years. In untabulated analysis, we find that publishing is generally similar for these multiple switchers compared to single switchers both for all sample years and separately for transitional and non-transitional years (two-tailed $p$-values $>0.089$ ). Based on univariate analysis, multiple switchers also publish more in the transitional years compared to the non-transitional years (one-tailed $p$-values ranging from 0.003 to 0.028 ). In the multivariate regressions for this subsample, the TRANSYR coefficients are positive in the logit and OLS models (two-tailed $p$-value $=0.118$ and 0.026 , respectively)

In our main analysis, we use a three-year transitional period centered on the switch year (years $-1,0,+1)$. As a sensitivity test, we use a five-year transitional period adding years -2 and +2 . In untabulated analysis using this wider window, we find univariate results for the full sample that are similar to Table 2 Panel A. When we use the five-year window for switches at least seven years after the author's Ph.D., however, we find that mean PUB and PUBNUM are statistically similar between transitional and non-transitional years. When we repeat the regression analysis in Table 3 Panel A using the five-year window, we find that the transitional effect is positive and significant only for switches that occur less than seven years after the author's Ph.D.

When we employ the five-year transitional period for the Hasselback rank sample used in Table 2 Panels C and D and Table 3 Panels B and C, we obtain the following untabulated results. In contrast to Table 2 Panels $\mathrm{C}$ and $\mathrm{D}$, we do not find any evidence that $P U B$ and $P U B N U M$ are higher in transitional compared to non-transitional years. When we repeat the regression analysis in Table 3 Panel B and use the five-year transitional period, we find that the transitional effect is positive and significant only for switches of tenured faculty (associate and full professors). When 
we use the five-year transitional period for switches at least 15 years after an author's Ph.D. (Table 3 Panel C), we do not find evidence of a transitional effect.

\section{DISCUSSION AND CONCLUSION}

Our study examines whether accounting professors ramp up research activity around a switch in university affiliation. Using a sample consisting of 635 switchers, 4,312 author-year observations, and 1,258 publications, we observe a significant increase in research productivity around a change in institutional affiliation. Although this increase is partially driven by a large number of switches and high publication activity occurring within four to nine years after faculty receive their doctorate, we still observe some evidence of an increase in research productivity around switches occurring in a longer time period after graduation and around switches among tenured professors. We also find that the increase in research productivity is similar between switches to more and less research-focused institutions.

One explanation for this phenomenon is offered by studies investigating the contract year performances of professional athletes (e.g., Martin et al., 2011; White \& Sheldon, 2014). These studies find a significant performance boost among athletes in the year before a contract year and in the contract year itself, consistent with expectancy theories (Bandura, 1997; Vroom, 1964). We also included the year after a university change as a transitional (or contract year) period due to the lag time in journal publications. In this study, we document a similar contract year effect (or syndrome) operating among accounting professors. Our research contributes to the higher education literature by being the first to investigate this contract year phenomenon within accounting academia. 


\section{Limitations and Future Research}

This study has limitations. First, similar to prior studies in this area (e.g., Bailey, 2015; Glover et al., 2012; Holderness, Myers, Summers, \& Wood, 2014), our sample is restricted to switchers who have published in BYU-listed journals. To the extent that authors who publish in journals outside of the BYU database (and the institutions that hire them) fundamentally differ from those who publish in the BYU-listed journals, the ability to generalize our results is limited. Second, we are unable to discern the direction of causality in our study. Some accounting professors may deliberately increase their research efforts in order to secure an alternative academic appointment, while others may have a paper accepted for publication, immediately recognize that this makes them more marketable, and then decide to pursue a position at a different institution. Future research that investigates the underlying cognitive processes that motivate productivity (cf. Becker, Kernan, Clark, \& Klein, 2018) around institutional changes could help determine causality. Such research would be of interest to academics and university administrators.

Finally, we examine only one dimension of faculty performance, scholarly publications. It is likely that other aspects of performance are also affected by changes in institutional affiliations. For example, faculty may shirk in the areas of teaching and service as they devote more time to research. Alternatively, faculty may work to improve teaching ratings to complement their research portfolios. Future research that examines whether and how the teaching and service dimensions of faculty performance change during transition periods would significantly contribute to the literature. 
Our study has practical implications for college administrators. Institutional success depends upon the successful competition for human talent (Fogarty \& Black, 2015). Our findings should sensitize administrators and search committees to the contract year syndrome operating within accounting academia when making job offer decisions. Deans, directors, and department chairs seek to hire and retain accounting professors who will enhance their programs. One way in which accounting programs are enhanced is through the publication record of faculty members (Coyne et al., 2010). Because of the contract year syndrome occurring, administrators should be aware that research productivity may fall off for new faculty and schools may lose currently productive researchers to other institutions. To reduce these negative effects, administrators need to cultivate an environment that provides adequate motivation for researchers. Administrators should focus on fostering an environment that promotes sustainable motivation among faculty, or otherwise risk losing productive researchers to other institutions and seeing some falloff in research productivity among resident faculty. 


\section{NOTES}

1 Restricting our sample to switchers is comparable to studies on the contract year performance of professional athletes that limit their samples to only athletes with a contract year during the sample period, as opposed to all athletes in the league (e.g., Martin et al., 2011; White \& Sheldon, 2014). In both cases, an extrinsic motivator is salient - new contracts for professional athletes and alternative professorial appointments for accounting authors.

2 Less well understood is whether this is a product of institutional advantages such as research expenditures (Podsakoff, MacKenzie, Podsakoff, \& Bachrach, 2008) or high-performing faculty gravitating towards departments that prioritize research (White, James, Burke, \& Allen, 2012).

3 Rankings in this study are based on six year ranking windows and the Coyne et al. (2010) journal index (cf. Coyne et al., 2010; Pickerd et al., 2011; Stephens et al., 2011). 


\section{REFERENCES}

Andrews, W. T., \& McKenzie, P. B. (1978). Leading accounting departments revisited. The Accounting Review, 53(1), 135-138.

Bailey, C. D. (2015). Psychopathy, academic accountants' attitudes towards unethical research: Practices and publication success. The Accounting Review, 90(4), 1307-1332.

Bandura, A. (1997). Self-efficacy: The exercise of control. New York, NY: W. H. Freeman.

Becker, T. E., Kernan, M. C., Clark, K. D., \& Klein, H. J. (2018). Dual commitments to organizations and professions: Different motivational pathways to productivity. Journal of Management, 44(3), 1202-1225.

Beckmann, K., \& Schneider, A. (2013). The interaction of publications and appointments: New evidence on academic economists in Germany. Education Economics, 21(4), 415-430.

Behling, O., \& Starke, F. A. (1973). The postulates of expectancy theory. Academy of Management Journal, 16(3), 373-388.

Bergner, J. M., Filzen, J. J., \& Wong, J. A. (2016). Navigating the accounting academic job market and related advice. Advances in Accounting Education, 19, 147-176.

Berri, D. J., \& Krautmann, A. C. (2006). Shirking on the court: Testing for the incentive effects of guaranteed pay. Economic Inquiry, 44(3), 536-546.

Boyle, D. M., Carpenter, B. W., \& Hermanson, D. R. (2015). The accounting faculty shortage: Causes and contemporary solutions. Accounting Horizons, 29(2), 245-264.

Bublitz, B., \& Kee, R. (1984). Measures of research productivity. Issues in Accounting Education, 2(1), 39-60.

Burke, K. G., Fender, B. F., \& Taylor, S. W. (2008). Swinging for the fences: Human capital and workplace characteristics of accountants publishing in top journals. The Accounting Educators' Journal, 18, 29-46.

Campbell, D., Gaertner, J., \& Vecchio, R. (1983). Perceptions of promotion and tenure criteria: A survey of accounting educators. Journal of Accounting Education, 1, 83-92.

Chan, K. C., Chang, C. H., Tong, J. Y., \& Zhang, F. (2014). A long-term assessment of research productivity in accounting and finance departments in UK: 1991-2010. Managerial Finance, 40(4), 416-431. 
Chan, K. C., Chen, C. R., \& Steiner, T. L. (2002). Production in the finance literature, institutional reputation, and labor mobility in academia: A global perspective. Financial Management, 31(4), 131-156.

Chen, Y, \& Zhao, Q. (2013). Gender differences in business faculty's research motivation. Journal of Education for Business, 88(6), 314-324.

Coyne, J. G., Summers, S. L., \& Wood, D. A. (2010). Accounting program research rankings by topical area and methodology. Issues in Accounting Education, 25(4), 631-654.

Fogarty, T. J. (2009). Show me the money: Academic research as currency. Accounting Education, $18(1), 3-6$.

Fogarty, T. J., \& Black, W. H. (2015). The reduced opportunity structure: Senior faculty movement in accounting 1980-2012. Issues in Accounting Education, 30(3), 207-231.

Fogarty, T. J., \& Jonas, T. A. (2013). Author characteristics for major accounting journals: Differences among similarities 1989-2009. Issues in Accounting Education, 28(4), 731757.

Fogarty, T. J., \& Ruhl, J. M. (1997). Institutional antecedents of accounting faculty research productivity: A LISREL study of the "best and brightest." Issues in Accounting Education, 12(1), 27-48.

Fogarty, T. J., \& Yu, W. (2010). The sustainability of success: Distinguishing the lucky from the good in the stacked deck of academic accounting. The Accounting Educator's Journal, 20, 63-89.

Glover, S. M., Prawitt, D. F., \& Wood, D. A. (2006). Publication records of faculty promoted at the top 75 accounting research programs. Issues in Accounting Education, 21(3), 195-218.

Glover, S. M., Prawitt, D. F., Summers, S. L, \& Wood, D. A. (2012). Publication benchmarking data based on faculty promoted at the top 75 U.S. accounting research institutions. Issues in Accounting Education, 27(3), 647-670.

Hasselback, J. R. (2009-2010 through 2015-2016). Accounting Faculty Directory. Englewood Cliffs, NJ: Prentice Hall.

Hasselback, J. R., \& Reinstein, A. (1995). A proposal for measuring scholarly productivity of accounting faculty. Issues in Accounting Education, 10(2), 269-306.

Hasselback, J. R., Reinstein, A, \& Schwan, E. S. (2000). Benchmarks for evaluating the research productivity of accounting faculty. Journal of Accounting Education, 18(2), 79-97. 
Holden, E. C., \& Sommers, P. M. (2005). The influence of free-agent filing on MLB player performance. Atlantic Economic Journal, 33(4), 489-490.

Holderness, D. K., Jr., Myers, N. M., Summers, S. L., \& Wood, D. A. (2014). Accounting education research: Ranking institutions and individual scholars. Issues in Accounting Education, 29(1), 87-115.

Jacobs, F. A., Hartgraves, A. L., \& Beard, L. H. (1986). Publication productivity of doctoral alumni: A time-adjusted model. The Accounting Review, 61(1), 179-187.

Jex, S. M., \& Britt, T. W. (2008). Organizational psychology: A scientist-practitioner approach. New York, NY: Wiley.

MacRoberts, M. H., \& MacRoberts, B. R. (1989). Problems of citation analysis: A critical review. Journal of the American Society for Information Science, 40(5), 342-349.

MacRoberts, M. H., \& MacRoberts, B. R. (1996). Problems of citation analysis. Scientometrics, $36(3), 435-444$.

Maranto, C. L., \& Streuly, C. A. (1994). The determinants of accounting professors' publishing productivity-the early career. Contemporary Accounting Research, 10(2), 387-407.

Martin, J. A., Eggleston, T. M., Seymour, V. A., \& Lecrom, C. W. (2011). One-hit wonders: A study of contract-year performance among impending free agents in major league baseball. NINE: A Journal of Baseball History and Culture, 20(1), 11-26.

Pickerd, J., Stephens, N. M., Summers, S. L., \& Wood, D. A. (2011). Individual accounting faculty research rankings by topical area and methodology. Issues in Accounting Education, 26(3), 471-505.

Podsakoff, P. M., MacKenzie, S. B., Podsakoff, N. P., \& Bachrach, D. G. (2008). Scholarly influence in the field of management: A bibliometric analysis of the determinants of university and author impact in the management literature in the past quarter century. Journal of Management, 34(4), 641-720.

Reinstein, A., Hasselback, J. R., Riley, M. E., \& Sinason, D. H. (2011). Pitfalls of using citation indices for making academic accounting promotion, tenure, teaching load, and merit pay decisions. Issues in Accounting Education, 26(1), 99-131.

Schwab, D. P. (1991). Contextual variables in employee performance-turnover relationships. Academy of Management Journal, 34(4), 966-975.

Smart, J. (1990). A causal model of faculty turnover intentions. Research in Higher Education, $31(5), 405-424$. 
Stephens, N. M., Summers, S. L., Williams, B., \& Wood, D. A. (2011). Accounting doctoral program rankings based on research productivity of program graduates. Accounting Horizons, 25(1), 149-181.

Stevens, K. T., \& Stevens, W. P. (1996). Ranking accounting doctoral programs by the research productivity of graduates: 1974-1992. Accounting Educators' Journal, 8(1), 51-79.

Stiroh, K. J. (2007). Playing for keeps: Pay and performance in the NBA. Economic Inquiry, 45(1), 145-161.

Swanson, E. (2004). Publishing in the majors: A comparison of accounting, finance, management and marketing. Contemporary Accounting Research, 21(1), 223-255.

Swanson, E. P., Wolfe, C. J., \& Zardkoohi, A. (2007). Concentration in publishing at top-tier business journals: Evidence and potential explanations. Contemporary Accounting Research, 24(4). 1255-1289.

White, C. S., James, K., Burke, L. A., \& Allen, R. S. (2012). What makes a "research star"? Factors influencing the research productivity of business faculty. International Journal of Productivity and Performance. 61(6). 584-602.

White, M., \& Sheldon, K. (2014). The contract year syndrome in the NBA and MLB: A classic undermining pattern. Motivation and Emotion, 38(2), 196-205.

Wood, D. A. (2016). Comparing the publication process in accounting, economics, finance, management, marketing, psychology, and the natural sciences. Accounting Horizons, 30(3), 341-361.

Vroom, V. H. (1964). Work and motivation. Oxford, UK: Wiley. 
Panel A: Mean publication dummy and number of publications by event year:

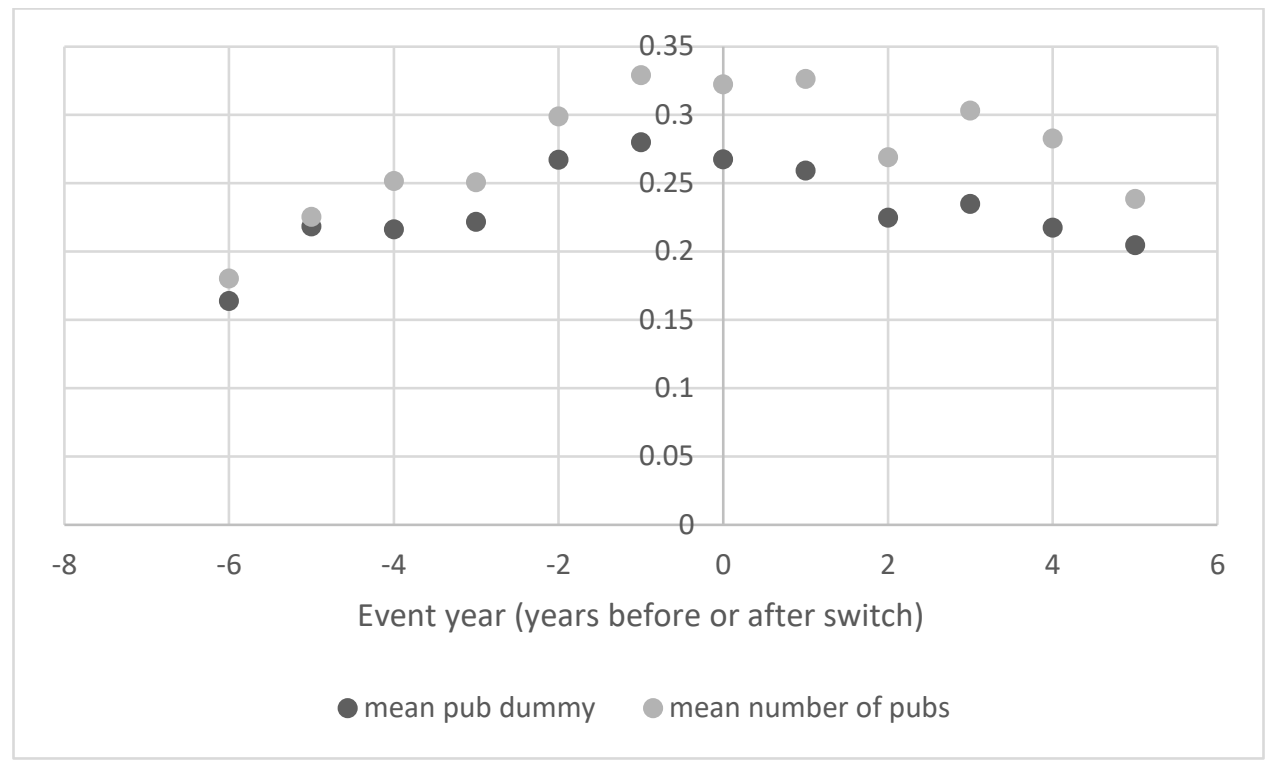

Panel B: Mean publication dummy and number of publications by years after Ph.D. graduation:

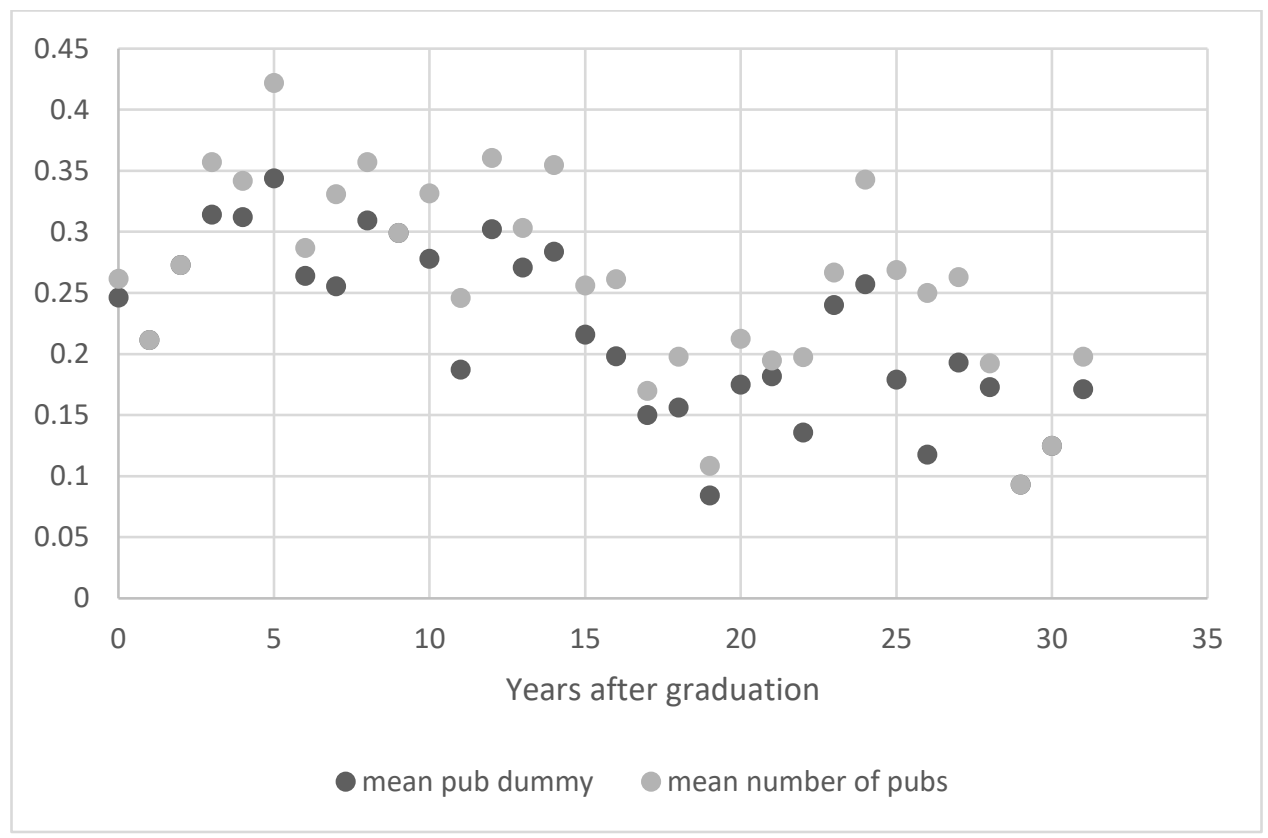


Panel C: Number of Switches by Years after Ph.D. Graduation:

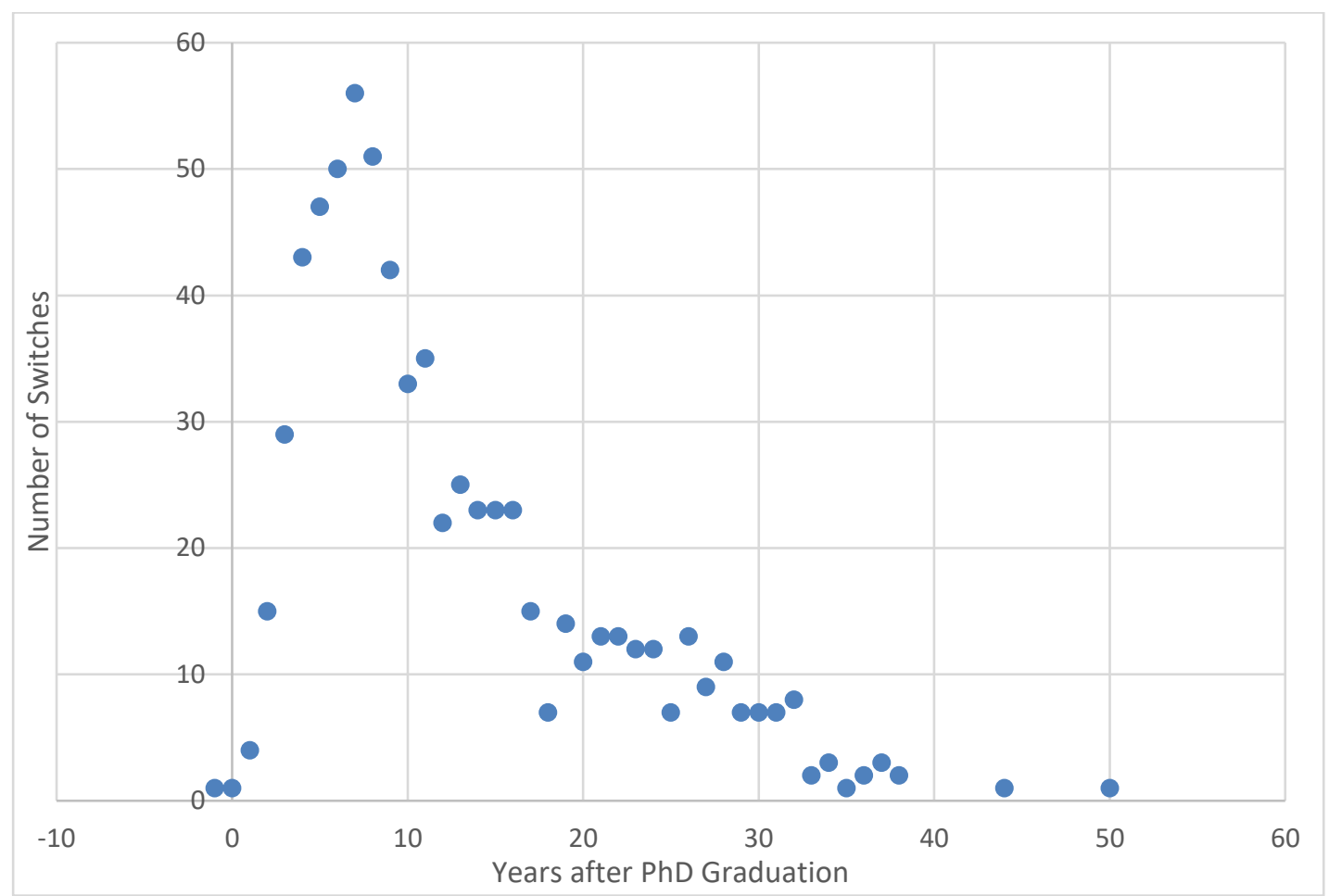

Fig. 1. Variable Relations. 
Table 1. Descriptive Statistics and Correlations among Variables.

Panel A: Descriptive Statistics

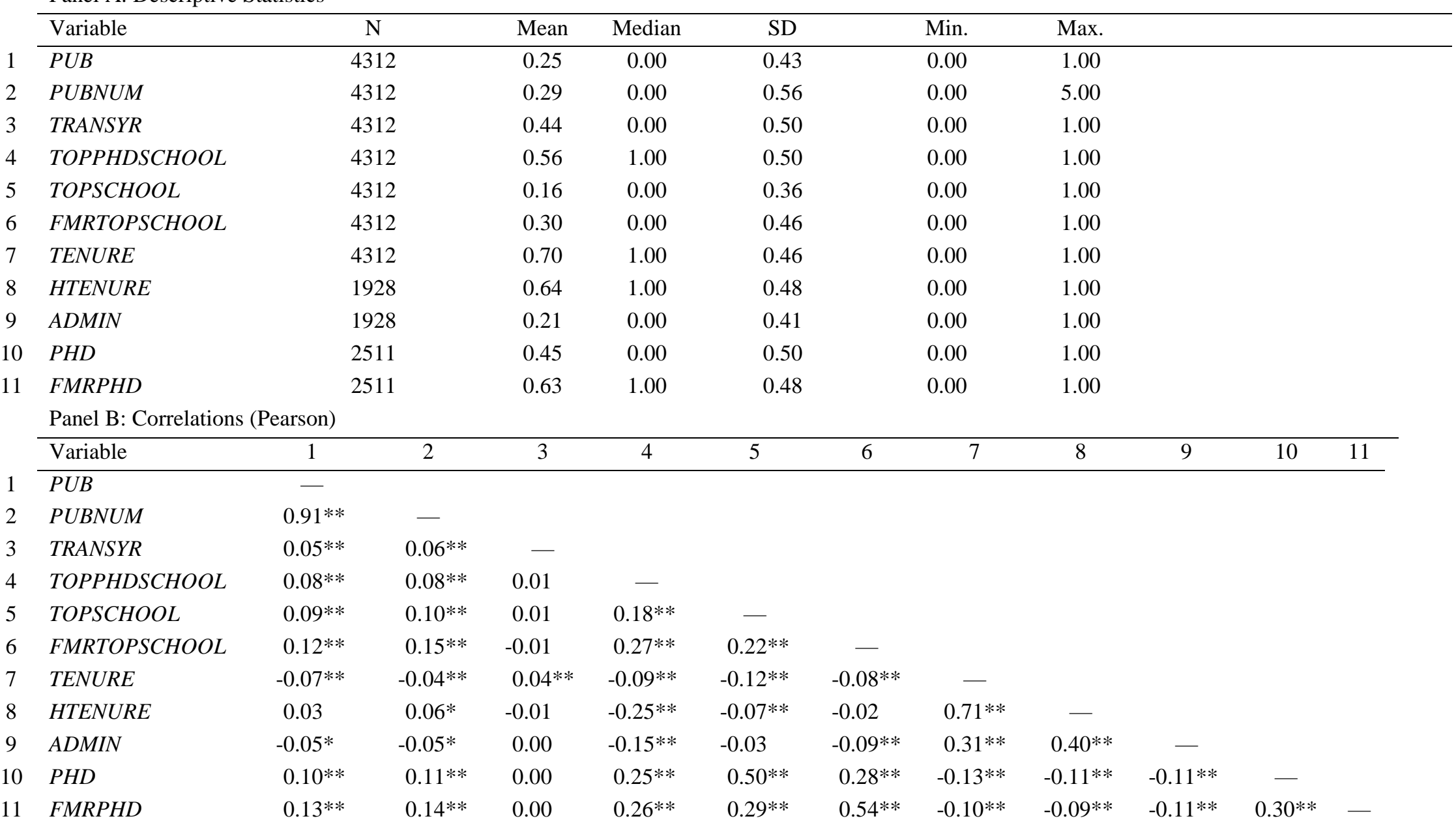


* Significant at the $p<0.05$ level (two-tailed).

** Significant at the $p<0.01$ level (two-tailed).

Variable Definitions:

$P U B=1$ if author published in year $t, 0$ otherwise.

$P U B N U M=$ number of publications in year $t$.

TRANSYR $=1$ if year $t$ is a transitional period year for author (i.e., year before switch, year of switch, or year after switch), 0 otherwise.

TOPPHDSCHOOL $=1$ if author's doctoral school is a top 40 program according to Stephens et al. (2011), 0 otherwise.

TOPSCHOOL $=1$ if institution to which the author switched is a top 40 program according to Coyne et al. (2010), 0 otherwise.

FMRTOPSCHOOL $=1$ if institution from which the author switched is a top 40 program according to Coyne et al. (2010), 0 otherwise.

TENURE $=1$ if author graduated from doctoral program at least seven years prior to year $t, 0$ otherwise.

$H T E N U R E=1$ if author is ranked as "Associate" or "Professor" in all available years (at least five of the six) in the Hasselback directories, 0 if author is ranked "Assistant" in all available years (at least five of the six).

$A D M I N=1$ if author has an administrative position in all available years in the Hasselback directories, 0 otherwise.

$P H D=1$ if institution to which the author switched has an accounting doctoral program listed in the Hasselback 2015-2016 edition, the program is active, and the program has at least 10 graduates in its history, 0 otherwise.

$F M R P H D=1$ if institution from which the author switched has an accounting doctoral program listed in the Hasselback 2015-2016 edition, the program is active, and the program has at least 10 graduates in its history, 0 otherwise. 
Table 2. Paired-Sample Tests of Differences in Publication Productivity between Transitional and NonTransitional Years.

\begin{tabular}{|c|c|c|c|c|c|c|c|}
\hline \multirow[b]{2}{*}{ Panel A: Full Sample } & \multirow[b]{2}{*}{ TRANSYR $=1$} & \multirow[b]{2}{*}{ TRANSYR $=0$} & \multirow{2}{*}{$\begin{array}{c}\text { Mean } \\
\text { Difference }\end{array}$} & \multicolumn{2}{|c|}{$\underline{\text { T-test }}$} & \multicolumn{2}{|c|}{$\underline{\text { Wilcoxon }}$} \\
\hline & & & & Test statistic & $p$-value & Test statistic & $p$-value \\
\hline Number of author-years (N) & 1927 & 2385 & & & & & \\
\hline Number of PUB $=1$ observations & 539 & 518 & & & & & \\
\hline Mean PUB & $26.9 \%$ & $22.6 \%$ & & 3.230 & 0.001 & 3.249 & 0.001 \\
\hline Mean PUBNUM & 0.33 & 0.26 & & 3.680 & 0.000 & 3.399 & 0.000 \\
\hline Median PUBNUM & 0.00 & 0.00 & & & & & \\
\hline Min. PUBNUM & 0.00 & 0.00 & & & & & \\
\hline Max. PUBNUM & 5.00 & 4.00 & & & & & \\
\hline \multicolumn{8}{|l|}{ Difference in means by author $(\mathrm{N}=623)$ : } \\
\hline PUB & & & $3.3 \%$ & 2.483 & 0.007 & 6631.5 & 0.014 \\
\hline PUBNUM & & & 0.05 & 2.890 & 0.002 & 8518.0 & 0.002 \\
\hline Panel B: Switches > 6 yrs. after Ph.D. & TRANSYR = 1 & TRANSYR $=0$ & Difference & Test statistic & $p$-value & Test statistic & $p$-value \\
\hline Number of author-years $(\mathrm{N})$ & 1376 & 1760 & & & & & \\
\hline Number of PUB $=1$ observations & 337 & 379 & & & & & \\
\hline Mean PUB & $24.5 \%$ & $21.5 \%$ & & 1.950 & 0.026 & 1.958 & 0.025 \\
\hline Mean PUBNUM & 0.30 & 0.25 & & 2.270 & 0.012 & 2.058 & 0.020 \\
\hline Median PUBNUM & 0.00 & 0.00 & & & & & \\
\hline Min. PUBNUM & 0.00 & 0.00 & & & & & \\
\hline Max. PUBNUM & 5.00 & 4.00 & & & & & \\
\hline \multicolumn{8}{|l|}{ Difference in means by author $(\mathrm{N}=446)$ : } \\
\hline PUB & & & $2.6 \%$ & 1.840 & 0.033 & 2196.5 & 0.014 \\
\hline PUBNUM & & & 0.04 & 1.995 & 0.023 & 2580.5 & 0.086 \\
\hline
\end{tabular}




\begin{tabular}{|c|c|c|c|c|c|c|c|}
\hline Panel C: Switches > 14 yrs. after Ph.D. & TRANSYR $=1$ & TRANSYR $=0$ & Difference & Test statistic & $p$-value & Test statistic & $p$-value \\
\hline Number of author-years $(\mathrm{N})$ & 604 & 796 & & & & & \\
\hline Number of $P U B=1$ observations & 115 & 124 & & & & & \\
\hline Mean $P U B$ & $19.0 \%$ & $15.6 \%$ & & 1.690 & 0.046 & 1.704 & 0.044 \\
\hline Mean PUBNUM & 0.24 & 0.19 & & 1.510 & 0.066 & 1.683 & 0.046 \\
\hline Median PUBNUM & 0.00 & 0.00 & & & & & \\
\hline Min. PUBNUM & 0.00 & 0.00 & & & & & \\
\hline Max. PUBNUM & 5.00 & 4.00 & & & & & \\
\hline \multicolumn{8}{|l|}{ Difference in means by author $(\mathrm{N}=200)$ : } \\
\hline$P U B$ & & & $3.2 \%$ & 1.690 & 0.046 & 489.5 & 0.067 \\
\hline PUBNUM & & & 0.04 & 1.409 & 0.080 & 356.5 & 0.142 \\
\hline Panel D: Switches for assoc./full & TRANSYR $=1$ & TRANSYR $=0$ & Difference & Test statistic & $p$-value & Test statistic & $p$-value \\
\hline Number of author-years (N) & 540 & 685 & & & & & \\
\hline Number of $P U B=1$ observations & 171 & 188 & & & & & \\
\hline Mean $P U B$ & $31.7 \%$ & $27.4 \%$ & & 1.610 & 0.054 & 1.611 & 0.054 \\
\hline Mean PUBNUM & 0.41 & 0.33 & & 2.150 & 0.016 & 1.781 & 0.038 \\
\hline Median PUBNUM & 0.00 & 0.00 & & & & & \\
\hline Min. PUBNUM & 0.00 & 0.00 & & & & & \\
\hline Max. PUBNUM & 5.00 & 3.00 & & & & & \\
\hline \multicolumn{8}{|l|}{ Difference in means by author $(\mathrm{N}=174)$ : } \\
\hline$P U B$ & & & $2.6 \%$ & 1.105 & 0.135 & 232.5 & 0.286 \\
\hline$P U B N U M$ & & & 0.05 & 1.564 & 0.060 & 521.5 & 0.105 \\
\hline
\end{tabular}

Notes:

See variable definitions in Table 1.

The $p$-values reported are one-tailed. 
Table 3. Regression Analyses of Switchers' Research Productivity.

Panel A: Full Sample

$\underline{\text { Variables }}$

Intercept

TRANSYR

TENURE

TRANSYR*TENURE

TOPPHDSCHOOL

TOPSCHOOL

FMRTOPSCHOOL

Test of $\beta_{1+} \beta_{3}=0$

$p$-value

$\mathrm{N}$

$-2 \log$ likelihood

Chi-square

$p$-value

Pseudo $\mathrm{R}^{2}$

F-stat

$p$-value

Adjusted $\mathrm{R}^{2}$
Logit $(P U B)$

OLS (PUBNUM)

Expec

\begin{tabular}{c}
\hline Coefficient \\
\hline-1.403 \\
0.307 \\
-0.225 \\
-0.084 \\
0.178 \\
0.326 \\
0.476
\end{tabular}

$\frac{\underline{\text { Odds }}}{-}$
1.360
0.799
0.919
1.195
1.385
1.609

$p$-value

0.000

0.014

0.039

0.574

0.067

0.006

0.000

6.416

0.011

4,312

4802.9

109.8

0.00

0.037

The $p$-values reported are two-tailed.

See variable definitions in Table 1. 
Panel B: Asst./Assoc./Full

$\underline{\text { Variables }}$

Intercept

TRANSYR

HTENURE

TRANSYR*HTENURE

TOPPHDSCHOOL

TOPSCHOOL

FMRTOPSCHOOL

ADMIN

Test of $\beta_{1+} \beta_{3}=0$

$p$-value

$\mathrm{N}$

$-2 \log$ likelihood

Chi-square

$p$-value

Pseudo $\mathrm{R}^{2}$

F-stat

$p$-value

Adjusted $\mathrm{R}^{2}$
Logit $(P U B)$

$\frac{\text { Expected Sign }}{?}$

$+$

$+$

$-$

$-$

$+$

$+$

$+$

$+$

Co

OLS (PUBNUM)

$\begin{array}{ccc}\text { Coefficient } & & \underline{p \text {-value }} \\ 0.169 & & 0.000 \\ 0.065 & 0.107 \\ 0.116 & 0.005 \\ 0.022 & 0.691 \\ 0.028 & 0.528 \\ 0.154 & 0.016 \\ 0.141 & 0.003 \\ -0.106 & 0.066 \\ & 3.04 \\ & 0.081 \\ & 1,928\end{array}$

8.14

0.00

0.041

The $p$-values reported are two-tailed.

See variable definitions in Table 1. 
Panel C: Switches > 14 yrs. after Ph.D.

$\underline{\text { Variables }}$

Intercept

TRANSYR

TOPPHDSCHOOL

\section{TOPSCHOOL}

FMRTOPSCHOOL

$\mathrm{N}$

$-2 \log$ likelihood

Chi-square

$p$-value

Pseudo $\mathrm{R}^{2}$

F-stat

$p$-value

Adjusted $\mathrm{R}^{2}$

The $p$-values reported are two-tailed.
See variable definitions in Table 1.
Logit $(P U B)$

Expected Sign

$?$

$+$

$+$

$+$

$+$

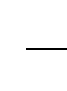

OLS (PUBNUM)

\begin{tabular}{|c|c|c|c|c|}
\hline$\underline{\text { Coefficient }}$ & $\underline{\text { Odds }}$ & $p$-value & $\underline{\text { Coefficient }}$ & $p$-value \\
\hline-1.972 & - & 0.000 & 0.143 & 0.000 \\
\hline 0.250 & 1.284 & 0.062 & 0.044 & 0.129 \\
\hline 0.299 & 1.348 & 0.166 & 0.053 & 0.208 \\
\hline 0.021 & 1.021 & 0.948 & -0.047 & 0.433 \\
\hline \multirow[t]{9}{*}{0.410} & 1.507 & 0.091 & 0.109 & 0.069 \\
\hline & & 1,400 & & 1,400 \\
\hline & & 1279.6 & & \\
\hline & & 16.7 & & \\
\hline & & 0.00 & & \\
\hline & & 0.020 & & \\
\hline & & & & 4.79 \\
\hline & & & & 0.00 \\
\hline & & & & 0.011 \\
\hline
\end{tabular}


Table 4. Switches to Research Universities.

Panel A: Switches to Top 40

\begin{tabular}{clcc} 
Number of switches (\% of all switches) & \multicolumn{2}{c}{ Former School } \\
\cline { 2 - 4 } Target School & Top 40 & $53(9 \%)$ & Not top 40 \\
\cline { 2 - 4 } & Not top 40 & $128(23 \%)$ & $38(7 \%)$ \\
& & \multicolumn{2}{c}{ N $=565$}
\end{tabular}

Panel B: Switches to Top 40

$\frac{\text { Variables }}{\text { Intercept }}$

TRANSYR

TOPSCHOOL

TRANSYR*TOPSCHOOL

TOPPHDSCHOOL

FMRTOPSCHOOL

Test of $\beta_{1+} \beta_{3}=0$

$p$-value

$\mathrm{N}$

-2 log likelihood

Chi-square

$p$-value

Pseudo R ${ }^{2}$

F-stat

$p$-value

Adjusted R ${ }^{2}$
TENURE
Logit $(P U B)$

\begin{tabular}{|c|c|c|c|}
\hline \multicolumn{4}{|l|}{ Expected } \\
\hline$\underline{\text { Sign }}$ & Coefficient & $\underline{\text { Odds }}$ & $p$-value \\
\hline$?$ & -1.343 & - & 0.000 \\
\hline+ & 0.240 & 1.271 & 0.002 \\
\hline - & 0.324 & 1.382 & 0.026 \\
\hline - & -0.029 & 0.971 & 0.875 \\
\hline+ & 0.154 & 1.166 & 0.135 \\
\hline+ & 0.466 & 1.594 & 0.000 \\
\hline- & -0.276 & 0.759 & 0.002 \\
\hline & & & 1.459 \\
\hline & & & 0.227 \\
\hline & & & 3,852 \\
\hline & & & 4303.4 \\
\hline & & & 94.1 \\
\hline & & & 0.00 \\
\hline & & & 0.036 \\
\hline
\end{tabular}

OLS (PUBNUM)

\begin{tabular}{|c|c|}
\hline Coefficient & $p$-value \\
\hline 0.208 & 0.000 \\
\hline 0.055 & 0.003 \\
\hline 0.085 & 0.042 \\
\hline 0.021 & 0.714 \\
\hline 0.034 & 0.184 \\
\hline 0.150 & 0.000 \\
\hline \multirow[t]{7}{*}{-0.030} & 0.174 \\
\hline & 2.800 \\
\hline & 0.095 \\
\hline & 3,852 \\
\hline & 20.15 \\
\hline & 0.00 \\
\hline & 0.030 \\
\hline
\end{tabular}

The $p$-values reported are two-tailed.

See variable definitions in Table 1. 
Panel C: Switches to Ph.D. Schools

\begin{tabular}{cllc} 
Number of switches (\% of all switches) & \multicolumn{2}{c}{ Former School } \\
& & Ph.D. & No Ph.D. \\
\cline { 2 - 4 } Target School & Ph.D. & $129(35 \%)$ & $35(9 \%)$ \\
& No Ph.D. & $103(28 \%)$ & $104(28 \%)$ \\
& & \multicolumn{2}{c}{ N $=371$}
\end{tabular}

\begin{tabular}{|c|c|c|c|c|c|c|}
\hline \multicolumn{2}{|c|}{ Panel D: Switches to Ph.D. Schools } & \multicolumn{3}{|c|}{ Logit $(P U B)$} & \multicolumn{2}{|c|}{ OLS $(P U B N U M)$} \\
\hline & Expected & & & & & \\
\hline$\underline{\text { Variables }}$ & $\underline{\text { Sign }}$ & $\underline{\text { Coefficient }}$ & $\underline{\text { Odds }}$ & $p$-value & Coefficient & $p$-value \\
\hline Intercept & $?$ & -1.654 & - & 0.000 & 0.158 & 0.000 \\
\hline TRANSYR & + & 0.135 & 1.145 & 0.338 & 0.040 & 0.163 \\
\hline PHD & - & 0.330 & 1.391 & 0.035 & 0.067 & 0.059 \\
\hline TRANSYR*PHD & - & 0.013 & 1.013 & 0.947 & 0.040 & 0.441 \\
\hline TOPPHDSCHOOL & + & 0.088 & 1.092 & 0.555 & 0.034 & 0.291 \\
\hline TENURE & - & -0.320 & 0.726 & 0.005 & -0.060 & 0.069 \\
\hline FORMERPHD & + & 0.764 & 2.146 & 0.000 & 0.175 & 0.000 \\
\hline Test of $\beta_{1+} \beta_{3}=0$ & & & & 1.303 & & 5.460 \\
\hline$p$-value & & & & 0.254 & & 0.020 \\
\hline $\mathrm{N}$ & & & & 2,511 & & 2,511 \\
\hline-2 log likelihood & & & & 2867.7 & & \\
\hline Chi-square & & & & 108.8 & & \\
\hline$p$-value & & & & 0.00 & & \\
\hline Pseudo $\mathrm{R}^{2}$ & & & & 0.062 & & \\
\hline F-stat & & & & & & 19.1 \\
\hline$p$-value & & & & & & 0.00 \\
\hline Adjusted $\mathrm{R}^{2}$ & & & & & & 0.044 \\
\hline
\end{tabular}

The $p$-values reported are two-tailed.

See variable definitions in Table 1. 